ORIGINAL ARTICLE

\title{
Chemical constituents, antioxidant, antimicrobial and anti-lipase activities of composites derived from green tea, lemon peels and red wine lees
}

\section{Constituintes químicos, atividades antioxidante, antimicrobiana e antilipase em compósitos derivados de chá verde, cascas de limão e borras de vinho tinto}

\author{
Levan Gulua ${ }^{1}$, Tamar Turmanidze ${ }^{1 *}$ (D), Merab Jgenti ${ }^{1}$ Manana Gurielidze ${ }^{2}$ \\ ${ }^{1}$ Agricultural University of Georgia, Department of Food Technology, Tbilisi/Georgia - USA \\ ${ }^{2}$ Agricultural University of Georgia, Durmishidze Institute of Biochemistry and Biotechnology, Tbilisi/Georgia - USA \\ *Corresponding Author: Tamar Turmanidze, Agricultural University of Georgia, Department of Food Technology, \\ David Aghmashenebeli Alley \#240, Kakha Bendukidze campus, Tbilisi/Georgia - USA, e-mail: \\ tturm2010@agruni.edu.ge
}

Cite as: Gulua, L., Turmanidze, T., Jgenti, M., \& Gurielidze, M. (2019). Chemical constituents, antioxidant, antimicrobial and anti-lipase activities of composites derived from green tea, lemon peels and red wine lees. Brazilian Journal of Food Technology, 22, e2018230. https://doi.org/10.1590/1981-6723.23018

\begin{abstract}
Novel sources of nutraceuticals, composites derived from green tea extract, red wine lees and lemon peels extract were produced. The first composite was produced from green tea extract and red wine lees. The second composite was produced from green tea extract, red wine lees and lemon peels. The composites intensively depressed the growth of the gram-positive bacteria Staphylococcus aureus and Rhodococcus sp. The inhibition zones for the first composite were 16.1 and $24.1 \mathrm{~mm}$, respectively and for the second composite - 18.5 and $24.3 \mathrm{~mm}$, respectively. In the case of the gram-negative bacteria Escherichia coli and Pseudomonas aeroginasa, the inhibition zones for the first composite were 18.1 and $6.1 \mathrm{~mm}$, and for the second composite - 6.1 and $10.2 \mathrm{~mm}$, respectively. In the case of the pathogenic fungi Rhizoctonia sp. and Streptomyces glaucus 71MD, the inhibition zones for the first composite were 14.7 and $22.3 \mathrm{~mm}$, and for the second composite -8.5 and $20.3 \mathrm{~mm}$, respectively. Both composites exhibited approximately 4 times less antioxidant potential than L-ascorbic acid and showed high levels of lipase inhibition, i.e. $12.3 \%$ and $10.5 \%$ per mg dry matter for the first and second composites, respectively. In comparison with Orlistat ${ }^{\circledR}$ they showed $30 \%$ less anti-lipase activity.
\end{abstract}

Keywords: Nutraceuticals; Antioxidants; Antimicrobial agents; Anti-lipase activity; Polyphenols; Tea; Wine; Citrus.

\section{Resumo}

Novas fontes de nutracêuticos, compósitos derivados de extrato de chá verde, borras de vinhos tintos e extratos de cascas de limão foram produzidas. O primeiro compósito foi produzido a partir de extrato de chá verde e borras de vinhos tintos. O segundo compósito foi produzido de extrato de chá verde, borras de vinhos tintos e cascas de limão. 
Os compósitos reduziram o crescimento das bactérias gram-positivas Staphylococcus aureus e Rhodococcus sp. As zonas de inibição para o primeiro compósito foram de 16,1 e 24,1 mm, respectivamente, e para o segundo compósito, 18,5 e 24,3 mm, respectivamente. No caso das bactérias gram-negativas Escherichia coli e Pseudomonas aeruginosa, as zonas de inibição para o primeiro compósito foram de 18,1 e 6,1 mm, respectivamente, e para o segundo compósito, 6,1 e 10,2 mm, respectivamente. No caso dos fungos patogênicos Rhizoctonia sp. e Streptomyces glaucus 71MD, as zonas de inibição para o primeiro compósito foram de 14,7 e 22,3 mm, respectivamente, e para o segundo compósito, 8,5 e 20,3 mm, respectivamente. Ambos os compósitos exibiram aproximadamente quatro vezes menos potencial antioxidante que ácido L-ascórbico e demonstraram altos níveis de inibição de lipase, ou seja, 12,3\% e 10,5\% por miligrama de matéria seca para o primeiro e segundo compósitos, respectivamente. Comparando com Orlistat ${ }^{\circledR}$, mostraram $30 \%$ a menos de atividade antilipase.

Palavras-chave: Nutracêuticos; Antioxidantes; Agentes antimicrobianos; Atividade antilipase; Polifenóis; Chá; Vinho; Citrus.

\section{Introduction}

The term "nutraceutical" is used with different meanings in different countries. According to the medicinal dictionary, nutraceutical is a food or naturally occurring food supplement thought to prevent disease or have other beneficial effects on human health. Since many people are concerned about the presence of "chemicals" in foods and worry about the possible ill effects of eating them, the search for novel natural bioactive compounds as sources of nutraceuticals is a real problem. With respect to this, polyphenols deserve special attention by the scientists (Feng et al., 2007; Rasouli et al., 2017).

White and green tea polyphenols inhibited pancreatic lipase in vitro, and could therefore be considered as nutraceuticals with an anti-obesity potential (Gondoin et al., 2010). Obesity is frequently associated with the intake of a lipid-rich diet. Pancreatic lipase (triacylglycerol acyl hydrolase EC 3.1.1.3) is an enzyme which plays a central role in lipid digestion and its subsequent absorption in humans. Consequently, dietary lipid absorption can be reduced by the partial inhibition of lipase activity and this is currently one of the main strategies used in the management and treatment of obesity (Birari \& Bhutani, 2007; Lunagariya et al., 2014).

The antioxidant activity of polyphenolic compounds has long been of primary interest (Halliwell, 1994) and there are several excellent reviews on the antioxidant activity of polyphenols (Cook \& Saman, 1996; Pandey \& Rizvi, 2009; Corina et al., 2017; Papuc et al., 2017).

Polyphenols are effective against a wide spectrum of microorganisms (Cowan, 1999; Coppo \& Marchese, 2014).

The tea plant, Camelia sinensis L., is rich in catechin type polyphenolics (Belitz et al., 2009) and other particularly rich sources of polyphenols are grapevines (Kader \& Barret, 2005; Balik et al, 2008).

There is also much data about the healthful properties of citrus polyphenols. The Critical Reviews in Food Science and Nutrition reported on the anti-inflammatory, antioxidant, lipid-lowering and insulin-sensitizing properties of the bioflavonoid hesperidin (Assini et al., 2013). Other research showed that the citrus bioflavonoid naringin displayed strong anti-inflammatory and antioxidant activities (Chanet et al., 2012).

However, the use of individual nutraceuticals to prevent diseases showed they had little effect when used alone. For instance, the antioxidant potential of tea is increased when lemon is added to it (Tewari et al., 2000). In addition, Researchers have shown synergetic effects with the use of citrus peel and the intake of black tea on the risk of squamous cell carcinoma of the skin (Hakim \& Harris, 2001). Thus, a complex "cocktail" of phenolic compounds could be better than single compound supplements. 
The tea plant, grapevine and citruses are commercially grown in Georgia. In addition, since these three plants are all rich in polyphenols, they were chosen as sources for plant composites with potentially high bioactivity.

A previous publication by the present authors briefly reported on the creation of nutraceuticals from green tea, red wine lees and lemon peels (Turmanidze et al., 2016). Thus the objective of the present work was to investigate the anti-lipase, antioxidant and antimicrobial activities of the new nutraceuticals.

\section{Materials and methods}

\subsection{Plant materials}

The green tea extract was courteously provided by the local JS company "Kolkheti 93", red wine lees produced from the Georgian Vitis vinifera variety "Saperavi" was provided by local wine producers, lemons of the Georgian variety "Kartuli" were commercially available at the local market.

\subsection{Chemicals}

Ascorbic acid, olive oil, sodium hydroxide, 2,4,6-Tris (2-pyridyl)-s-triazine (TPTZ) and Metahydroxydiphenyl were purchased from Sigma Aldrich (Steinheim, Germany). The Folin-Ciocalteu reagent was obtained from Appli Chem (Steinheim, Germany), sodium carbonate was from Chem Cruz Biochemicals (California, USA), the Tween 80 detergent was produced by Ferak Berlin GmbH (Berlin, Germany) and the pancreatic plant lipase concentrate was obtained from Integrative Therapeutics, (Green Bay, USA). Orlistat ${ }^{\circledR}$ (trade name Xenical), produced by Roche (Italy), was purchased at a local pharmacy. All other reagents were of analytical grade.

\subsection{Preparation of composites}

\subsubsection{Composite from green tea extract and red wine lees - the first composite}

The term "lees" was used to indicate the precipitate forming at the bottom of a barrel of wine after fermentation and aging and is therefore a by-product of the winemaking process. The composite was prepared by mixing liquid red wine lees with dry green tea powder, and subsequently spray drying to produce a powder. The wine lees were first left overnight in a cylindrical glass vessel at $4{ }^{\circ} \mathrm{C}$ in order to separate the insoluble sediment. After sedimentation, the clear supernatant was removed by decantation and filtered through a dense filter under vacuum. The filtered wine lees were heated to $60^{\circ} \mathrm{C}$ and the green tea dry extract gradually added in small portions with constant stirring. The ratio of the dry substances from the wine lees to those from the green tea extract was 1:2 respectively. The solution obtained was spray-dried using a PG-L-1.5 lab scale spray-dryer (Changzhou Xianfeng Best Drying Equipment and Engineering Co., Ltd, China) to produce a powder.

\subsubsection{Composite produced from green tea extract, red wine lees and lemon peels - the second composite}

The filtered supernatant from the red wine lees was poured into a vessel containing the pressed lemon peels (ratio of $6: 1 \mathrm{~m} / \mathrm{m}$ ), the mixture was heated to $80^{\circ} \mathrm{C}$, maintained at $80{ }^{\circ} \mathrm{C}$ for $15 \mathrm{~min}$ and then filtered through a dense filter under vacuum. The filtered extract was added to the green tea extract (1:2 respectively, based on the dry matter) and spray-dried to produce a powder. 


\subsection{Total Phenolic Content (TPC)}

An improved colorimetric assay using the Folin-Ciocalteu reagent was applied to determine the TPC in the plant materials (Bond et al., 2003). Duplicate $0.5 \mathrm{~g}$ aliquots of dry plant extract were introduced into $50 \mathrm{~mL}$ volumetric flasks. Hot water $\left(25 \mathrm{~mL}\right.$, maximum temperature $\left.60^{\circ} \mathrm{C}\right)$ was added to dissolve the sample and the solution then allowed to cool to room temperature. Acetonitrile $(5 \mathrm{~mL})$ was added to the cool sample, diluted to volume with deionised water and mixed well. The sample extract $(1.0 \mathrm{~mL})$ was pipetted into separate 100 $\mathrm{mL}$ volumetric flasks, diluted with water and mixed well.

The diluted sample extract $(1.0 \mathrm{~mL})$ and dilute gallic acid working standard solutions were pipetted in duplicate into separate disposable tubes. Dilute Folin-Ciocalteu phenol reagent $(5 \mathrm{~mL})$ was added to each tube. Between 3 and 8 min after addition of the Folin-Ciocalteu reagent, sodium carbonate solution $(4 \mathrm{~mL})$ was added to each tube, the tube stoppered and the solution mixed well.

The samples and standards were allowed to stand at room temperature for 60 minutes, and their optical densities then measured using a spectrophotometer set at $\lambda 765 \mathrm{~nm}$ with a $10 \mathrm{~mm}$ long cell, the value for zero being fixed using the reagent blank.

\subsubsection{Calculation}

A linear calibration graph was prepared using the standard gallic acid solutions, plotting the optical densities of the standard solutions (after subtracting the value of the reagent blank) against concentration. The straight line was adjusted to pass through zero and the standard slope for gallic acid obtained from the gradient of the straight line. The TPC ( $\mu$ g gallic acid equivalents) in the sample extract was determined from the optical density according to the standard gallic acid graph and the percent polyphenolic compounds then calculated on a sample mass basis.

\subsection{Pectic substances}

Pectic substances were quantitatively analysed using the meta-hydroxydiphenyl method (Blumenkrantz \& Asboe-Hansen, 1973). A purple colour is developed when uronic acid reacts with meta-hydroxydiphenyl and the colour intensity is proportional to the galacturonic acid concentration in the reaction mixture. A linear calibration graph was prepared using standard galacturonic acid solutions, plotting the optical densities at $520 \mathrm{~nm}$ (subtracting the value of the reagent blank) against concentration. The standard galacturonic acid solutions were between $0-15 \mathrm{mg} \cdot \mathrm{mL}^{-1}$ ).

\subsection{Amino acids}

The amino acids were determined using the ninhydrin colorimetric method (Friedman, 2004) with some modifications. $25 \mathrm{~mL}$ of the liquid plant extract were added together with acetone in a 1:3 (v/v) ratio, respectively. The mixture was left at room temperature for 3 hours and then centrifuged at $7000 \mathrm{~g}$ for $15 \mathrm{~min}$. The supernatant was poured into a ceramic cup and placed on a hot plate until complete evaporation. The dry extract was dissolved in $25 \mathrm{~mL}$ citrate phosphate buffer at $\mathrm{pH} 2.2$ and $2 \mathrm{~mL}$ of this solution added to $1 \mathrm{~mL}$ ninhydrin reagent ( $15 \mathrm{~mL}$ monomethyl, $5 \mathrm{~mL}$ acetate buffer $\mathrm{pH} 5.5,0.4 \mathrm{~g}$ ninhydrin, $0.008 \mathrm{~g} \mathrm{SnCl}_{2}$ ). The reaction mixture was placed in a thermostat at $80{ }^{\circ} \mathrm{C}$ for $40 \mathrm{~min}$ and the absorption of the violet coloured products measured at $570 \mathrm{~nm}$, subtracting the value of the reagent blank. A linear calibration graph was prepared using standard glutamic acid solutions, plotting the optical densities at $570 \mathrm{~nm}$ (subtracting the value of the reagent blank) against concentration $\left(0.01-0.1 \mathrm{mg} \cdot \mathrm{mL}^{-1}\right)$. 


\subsection{Lipase activity and percent inhibition}

The lipase activity and its percent inhibition were determined according to Stoytcheva et al. (2012) with minor modifications. Briefly, the initial reaction mixture consisted of $2.5 \mathrm{~mL}$ deionized water, $3 \mathrm{~mL}$ of olive oil, $1 \mathrm{~mL} 200 \mathrm{mM}$ Tris $\mathrm{HCl}$ buffer (pH 7.2) and $0.5 \mathrm{~mL}$ detergent (Tween 80). The mixture was mixed vigorously using a magnetic stirrer for $15 \mathrm{~min}$ in order to obtain a good emulsion. The lipase preparation $\left(150 \mathrm{mg}\right.$ ) was then added to the emulsified mixture and incubated at $37{ }^{\circ} \mathrm{C}$ for $30 \mathrm{~min}$. At the end of incubation, $3 \mathrm{~mL}$ of $95 \%$ alcohol were added and the final reaction mixture titrated with $50 \mathrm{mM} \mathrm{NaOH}$ using an automatic potentiometric titrator (ZDJ-4A, INESA Scientific Instrument Co., Ltd, Anting Shanghai, China). The end point for the titration was set at $\mathrm{pH}$ 9.0. A blank titration was carried out as above but without lipase. One unit of lipase activity was defined at that amount of lipase which hydrolyses 1.0 micro equivalent of fatty acid from a triglyceride in one hour at $\mathrm{pH} 7.2$ at $37^{\circ} \mathrm{C}$. The lipase activity was calculated according to the following formula:

Lipase Units $=(\mathrm{A}-\mathrm{B}) \times 1000 \times 2 \times \mathrm{DF}$

where:

$\mathrm{A}=$ the volume in $\mathrm{mL}$ of $50 \mathrm{mM} \mathrm{NaOH}$ consumed by the test sample

$\mathrm{B}=$ the volume in $\mathrm{mL}$ of $50 \mathrm{mM} \mathrm{NaOH}$ consumed by the blank sample

$1000=$ the conversion factor from milli equivalents to micro equivalents

$2=$ time conversion factor from $30 \mathrm{~min}$ to $1 \mathrm{~h}$

$\mathrm{DF}=$ dilution factor

The lipase inhibitory activity of the different wines was assessed by adding $1 \mathrm{ml}$ of wine to the reaction mixture described above. The reaction and subsequent titration were carried out as described above for the determination of lipase activity. The percent inhibition was calculated from the lipase activity obtained in the presence and absence of wine, both per $\mathrm{mL}$ of wine and per $\mathrm{mg}$ of non-volatile dry extract of wine. Orlistat $(20 \mathrm{mg})$ was used as the standard inhibitor compound. The lipase activity was measured in the presence of Orlistat and the percent inhibition calculated per mg of Orlistat.

\subsection{The Ferric Reducing Ability of Plasma (FRAP)}

The FRAP assay method was used to measure the antioxidant potential of the composites (Benzie \& Strain, 1996): in the presence of antioxidants the TPTZ- $\mathrm{Fe}^{3+}$ complex reduces to the TPTZ- $\mathrm{Fe}^{2+}$ form and an intense blue colour with an absorption maximum at $593 \mathrm{~nm}$ develops and the change in absorption is proportional to the concentration of antioxidants. The absorption was measured using a M501 spectrophotometer (Camspec Ltd, UK) and the antioxidant potential expressed as the concentration of $\left[\mathrm{Fe}^{2+}\right]$ ions produced during 4 minutes of reaction. The antioxidant potential of the composites was compared with that of L-ascorbic acid and an aqueous solution of $1000 \mu \mathrm{mol} \mathrm{L}^{-1} \mathrm{FeSO}_{4} \times 7 \mathrm{H}_{2} \mathrm{O}$ used to calibrate the instrument.

\subsection{Antimicrobial tests}

The agar well diffusion method was applied to measure the antimicrobial activity of the composites (Balouiri et al., 2016). The strains of test microorganisms were inoculated onto Petri plates containing agar media considered favourable for the growth of the microorganisms. $10 \%$ concentration solutions of the plant extracts were prepared in sterile water and $50 \mu \mathrm{L}$ aliquots placed in the agar wells $(12 \mathrm{~mm}$, diameter). The plates were incubated at $37^{\circ} \mathrm{C}$ for $24 \mathrm{~h}$. The antimicrobial potential of the plant extracts was estimated from the diameter $(\mathrm{mm})$ of the inhibition zone around the wells. All experiments were carried out in triplicate and the results averaged. 
The composites were tested against the following microorganisms: Gram positive bacteria Staphylococcus aureus and Rhodococcus sp., Gram negative bacteria - Escherichia coli and Pseudomonas aeroginasa; Yeasts - Candida utilis, Saccharomyces fragilis, Sacharomyces cerevisiae and Torulopsis sp., Pathogenic fungi - Fusarium solani and Rhizoctonia sp. The nutrient media for the incubation of the microorganisms were as follows: Nutrient agar for bacteria; Sabouraud agar for the yeasts and pathogenic fungi.

\subsection{Statistical analysis}

The data presented were the mean of three replicates \pm standard deviation. The data were subjected to a one-way analysis of variance and all calculations were done using Microsoft Excel (Version 4, statistical functions, Microsoft Corp., Redmond, WA, USA).

\section{Results and discussion}

\subsection{Assay of chemical constituents}

The biologically active components of plant materials such as polyphenols, amino acids, organic acids and pectin were determined quantitatively.

The green tea extract consisted of $23.50 \% \pm 0.91 \%$ TPC, $13.39 \% \pm 0.56 \%$ amino acids, $9.51 \% \pm 0.63 \%$ pectin and $5.30 \% \pm 0.42 \%$ organic acids (Table 1). The biological activities of polyphenols were already mentioned in the introduction section. A high content of amino acids is favourable for the creation of composites with high nutritional and biological values and pectic substances in combination with polyphenols can synergistically contribute to the antioxidant activity of the extract (Aprikian et al., 2003).

Table 1. Proximate chemical composition* of the plant materials (\% dry matter).

\begin{tabular}{ccccc}
\hline Plant material & TPC & Soluble pectin & Organic acids & Amino acids \\
\hline Green tea extract & $23.50 \pm 0.91^{\mathrm{a}}$ & $9.51 \pm 0.63^{\mathrm{a}}$ & $5.30 \pm 0.42^{\mathrm{a}}$ & $13.39 \pm 0.56^{\mathrm{a}}$ \\
Red wine lees & $16.42 \pm 0.66^{\mathrm{c}}$ & $12.81 \pm 0.55^{\mathrm{b}}$ & $27.70 \pm 0.78^{\mathrm{b}}$ & $19.05 \pm 0.64^{\mathrm{b}}$ \\
Lemon peel & $1.52 \pm 0.24^{\mathrm{d}}$ & $33.24 \pm 0.96^{\mathrm{b}}$ & $0.30 \pm 0.05^{\mathrm{c}}$ & $* * \mathrm{BDL}$ \\
Lemon pulp & $0.34 \pm 0.05^{\mathrm{e}}$ & $12.13 \pm 0.68^{\mathrm{d}}$ & $8.67 \pm 0.36^{\mathrm{d}}$ & $* * \mathrm{BDL}$ \\
$* * *$ GT+RWL+LP & $21.30 \pm 0.56^{\mathrm{b}}$ & $14.17 \pm 0.40^{\mathrm{e}}$ & $13.94 \pm 0.62^{\mathrm{e}}$ & $7.07 \pm 0.41^{\mathrm{c}}$ \\
$* * *$ GT+RWL & $17.33 \pm 0.59^{\mathrm{c}}$ & $11.52 \pm 0.35^{\mathrm{d}}$ & $16.01 \pm 0.62^{\mathrm{f}}$ & $15.36 \pm 0.54^{\mathrm{d}}$ \\
\hline
\end{tabular}

*The data presented are the mean of three replicates \pm standard deviation. Differences between data in the same column without the same superscript are significantly different at the $\alpha=0.05$ level. ${ }^{*}$ BDL-below detectable limit. $* * * \mathrm{GT}+\mathrm{RWL}+\mathrm{LP}-$ Green Tea + Red Wine Lees + Lemon Peels. ${ }^{* * * * G T+R W L-G r e e n ~ T e a ~}+$ Red Wine Lees.

Organic acids have a wide spectrum of antimicrobial activity (Tejero-Sariñena et al., 2012). Abundant polyphenols and pectin were found in the red wine lees $(16.42 \% \pm 0.66 \%$ and $12.81 \% \pm 0.55 \%$ respectively) (Table 1) which were also rich in amino acids and organic acids $-19.05 \% \pm 0.64 \%$ and $27.70 \% \pm 0.78 \%$ respectively (Table 1). Lees are a by-product of the winery industry with a relatively low price and Landeka et al. showed that wine lees polyphenols could be used as novel functional compounds (Landeka et al., 2017). Hence, it was proposed to compose a bioactive composite from green tea extract and red wine lees.

The pectin, organic acids and TPC contents were determined in the pulp and peel of the Georgian variety of lemon (Table 1). The lemon peel was a very rich source of polyphenols and pectin in comparison with the pulp. The polyphenol compound contents of the lemon peel and pulp were $300.01 \pm 5.51$ and $68.03 \pm 1.08 \mathrm{mg}$ per $100 \mathrm{~g}$, respectively. The pectin content of the lemon peel was $33.24 \% \pm 0.96 \%$ of dry matter and that of the pulp was $12.13 \% \pm 0.68 \%$. 
Therefore, lemon peel was also proposed as a commercial source for the production of bioactive composites.

Based on the results the second composite was composed of green tea and lemon peel extracts and red wine lees, presenting a full "cocktail" of polyphenols from these three plant materials.

The first and second composites contained large amounts of polyphenols: $17.33 \% \pm 0.59 \%$ and $21.30 \% \pm 0.56 \%$ respectively; soluble pectin $(14.17 \% \pm 0.40 \%$ and $11.52 \% \pm 0.35 \%)$, amino acids $(15.36 \% \pm 0.54 \%$ and $7.07 \% \pm 0.41 \%)$ and organic acids $(16.01 \% \pm 0.62 \%$ and $13.94 \% \pm 0.62 \%)$ (Table 1$)$. Accordingly, the plant composites should have a wide, ample spectrum of bioactivity.

\subsection{Antimicrobial assay}

The composites inhibited the growth of gram positive and negative bacteria and of the pathogenic fungi Rhizoctonia sp., Streptomyces glaucus 71 MD, but did not affect the growth of yeasts or of the pathogenic fungus Fusarium solani. The composites were highly active against the gram-positive bacteria Staphylococcus aureus and Rhodococcus sp and the pathogenic fungus Streptomyces glaucus 71MD. The growth inhibition zones for the first composite were $16.10 \pm 1.72 \mathrm{~mm}, 24.15 \pm 1.11 \mathrm{~mm}$ and $22.32 \pm 1.44 \mathrm{~mm}$ respectively. The growth inhibition zones for the second composite were $18.57 \pm 1.21 \mathrm{~mm}, 24.30 \pm 1.51 \mathrm{~mm}$ and $20.33 \pm 1.20 \mathrm{~mm}$ respectively (Table 2). The antimicrobial activities of the composites against Staphylococcus aureus, Rhodococcus sp and Streptomyces glaucus $71 M D$ were not statistically significantly different $(\alpha=0.05$ level). The inhibition zones of the growth of the gram-negative bacterium Escherichia coli was $18.17 \pm 1.31 \mathrm{~mm}$ for the first composite and $6.14 \pm 0.72 \mathrm{~mm}$ for the second composite. The first composite was less active against Pseudomonas aeroginasa $(6.30 \pm 0.65 \mathrm{~mm})$ than the second composite $(10.24 \pm 1.56 \mathrm{~mm})$. The growth inhibition zone for Rhizoctonia sp. was $14.75 \pm 1.09$ and $8.50 \pm 0.42 \mathrm{~mm}$ for the first and the second composites, respectively (Table 2).

Table 2. Antimicrobial activities* of the composites.

\begin{tabular}{|c|c|c|}
\hline \multirow[b]{2}{*}{ Microorganisms } & \multicolumn{2}{|c|}{ Inhibition zones (mm) } \\
\hline & $\begin{array}{c}\text { Composite of green tea, lemon peel extracts and } \\
\text { red wine lees }\end{array}$ & $\begin{array}{c}\text { Composite of green tea extract and } \\
\text { red wine lees }\end{array}$ \\
\hline \multicolumn{3}{|l|}{ Gram positive bacteria } \\
\hline Staphylococcus aureus & $18.57 \pm 1.21^{\mathrm{a}}$ & $16.10 \pm 1.72^{\mathrm{a}}$ \\
\hline Rhodococcus sp. & $24.30 \pm 1.51^{\mathrm{b}}$ & $24.15 \pm 1.11^{\mathrm{b}}$ \\
\hline \multicolumn{3}{|l|}{ Gram negative bacteria } \\
\hline Escherichia coli & $6.14 \pm 0.72$ & $18.17 \pm 1.31$ \\
\hline Pseudomonas aeroginasa & $10.24 \pm 1.56$ & $6.30 \pm 0.65$ \\
\hline \multicolumn{3}{|l|}{ Yeasts } \\
\hline Candida utilis, & No effect & No effect \\
\hline Sacharomyces cerevisiae & No effect & No effect \\
\hline \multicolumn{3}{|l|}{ Pathogenic fungi } \\
\hline Fusarium solani, & No effect & No effect \\
\hline Rhizoctonia $s p$ & $8.50 \pm 0.42$ & $14.75 \pm 1.09$ \\
\hline $\begin{array}{l}\text { Streptomyces glaucus } \\
\quad 71 M D\end{array}$ & $20.33 \pm 1.20^{\mathrm{c}}$ & $22.32 \pm 1.44^{\mathrm{c}}$ \\
\hline
\end{tabular}

*The data presented are the mean of two replicates \pm standard deviation. Differences between data in the same column are statistically significant at the $\alpha=0.05$ level. a, b, c Means in the same row with the same superscripts are not significantly different at the $\alpha=0.05$ level.

\subsection{Antioxidant assay}

The antioxidant potentials of Vitamin C (ascorbic acid) and of $23 \%$ and $97 \%$ green tea polyphenol compound extracts were used to compare with those of the composites. The antioxidant potentials of the composites and of the $23 \%$ green tea polyphenol compound extract were not statistically significantly 
different (Table 3). Both composites had approximately 4 times less activity than L-ascorbic acid and the antioxidant potential of the $97 \%$ green tea polyphenol compound extract was four times that of ascorbic acid.

Table 3. Antioxidant potential* of the plant materials and ascorbic acid.

\begin{tabular}{cc}
\hline Plant product & Antioxidant potential, $\left[\mathbf{F e}^{2+}\right] \mathbf{~ m M}$ \\
\hline 97\% green tea polyphenol compound extract & $40.25 \pm 0.85$ \\
23\% green tea polyphenol compound extract & $2.19 \pm 0.10^{\mathrm{a}}$ \\
ascorbic acid & $9.42 \pm 0.76$ \\
Composite of green tea extract and red wine lees & $2.33 \pm 0.35^{\mathrm{a}}$ \\
Composite of green tea and lemon peel extracts and red wine lees & $1.82 \pm 0.20^{\mathrm{a}}$ \\
\hline *The data presented are the mean of three replicates \pm standard deviation. ${ }^{\text {a }}$ Differences between data in the same column without the same \\
superscript are significantly different at the $\alpha=0.05$ level. The figures were calculated based on 1 $\mathrm{g} \mathrm{L}^{-1}$ concentration of the materials.
\end{tabular}

\subsection{Anti-lipase assay}

The anti-lipase activities of the composites were compared with that of orlistate, which is the only pancreatic lipase inhibitor in clinical use nowadays. Orlistat is a hydrogenated derivative of lipstatin, isolated from the Gram-positive bacterium Streptomyces toxytricini (Kang \& Park, 2012).

One mg of the first composite inhibited lipase activity by $12.30 \%$ and of the second one by $10.52 \%$, whereas Orlistat $₫$ inhibited lipase activity by $16.64 \%$ per mg dry matter. Thus, the composites only showed $30 \%$ less anti-lipase activity per mg dry matter than Orlistat ${ }^{\circledR}$ (Table 4$)$.

Table 4. Anti-lipase activity of the composites.

\begin{tabular}{ccccc}
\hline & Without inhibitor & First composite & Second composite & Orlistate \\
\hline Enzyme activity, Units per mg solids & $48.37 \pm 2.80^{\mathrm{a}}$ & $42.44 \pm 1.62^{\mathrm{b}}$ & $43.29 \pm 1.64^{\mathrm{b}}$ & $40.34 \pm 1.32^{\mathrm{c}}$ \\
Inhibition \% based on 1 mg solids & 0 & $12.30 \pm 0.80^{\mathrm{a}}$ & $10.52 \pm 0.71^{\mathrm{a}}$ & $16.64 \pm 0.93^{\mathrm{b}}$ \\
\hline
\end{tabular}

Values in the same row with different letters are significantly different according to ANOVA with Tukey's HSD tests, at $p<0.05$.

Gilles et al. reported that Khaya tea inhibited lipase activity up to an inhibitory percentage of $85 \% \pm 2 \%$ corresponding to $3 \mathrm{mg} \mathrm{mL}^{-1}$ khaya tea. Orlistat ${ }^{\circledR}$ also significantly inhibited lipase activity, but the effective concentrations were much lower than for khaya tea (Gilles et al., 2015).

Figures 1 and 2 represent inhibition of the lipase activity by different concentrations of the composites and by $97 \%$ green tea polyphenol compounds, respectively. As shown in the figures, the lipase activity decreased exponentially when the concentration of the inhibitors increased. Maximum inhibition was achieved at the concentrations of $10 \mathrm{mg} \mathrm{mL}^{-1}$ and $2 \mathrm{mg} \mathrm{mL}^{-1}$ for the composites and the $97 \%$ green tea polyphenol compounds, respectively.

The $\mathrm{IC}_{50}$ values representing the concentrations of the inhibitors which inhibited $50 \%$ of the lipase activity were $2.51 \pm 0.03 \mathrm{mg} \mathrm{mL}^{-1}$ and $0.52 \pm 0.02 \mathrm{mg} \mathrm{mL}^{-1}$ for the composites and for the $97 \%$ green tea polyphenol compounds, respectively. 


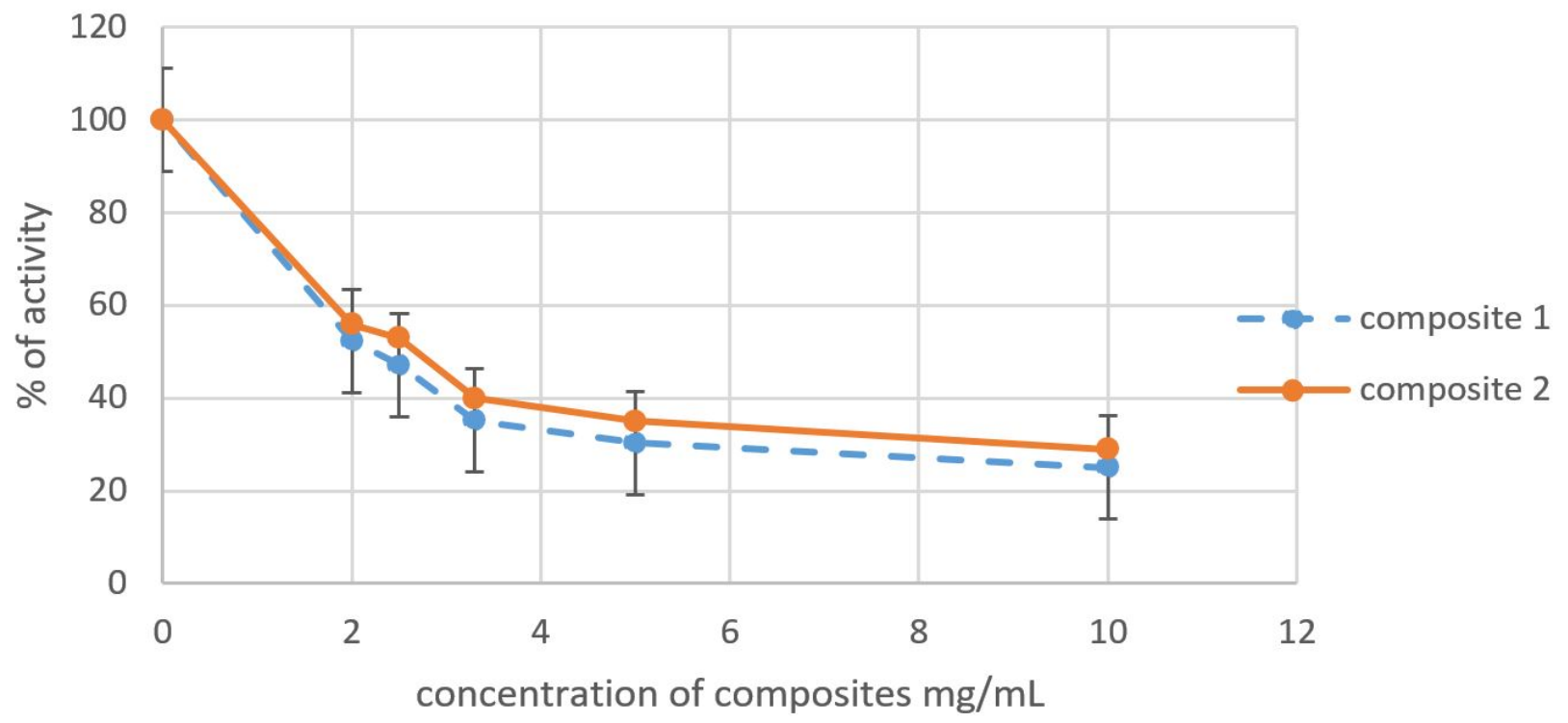

Figure 1. Inhibition of the lipase activity by different concentrations of the composites 1 and 2.

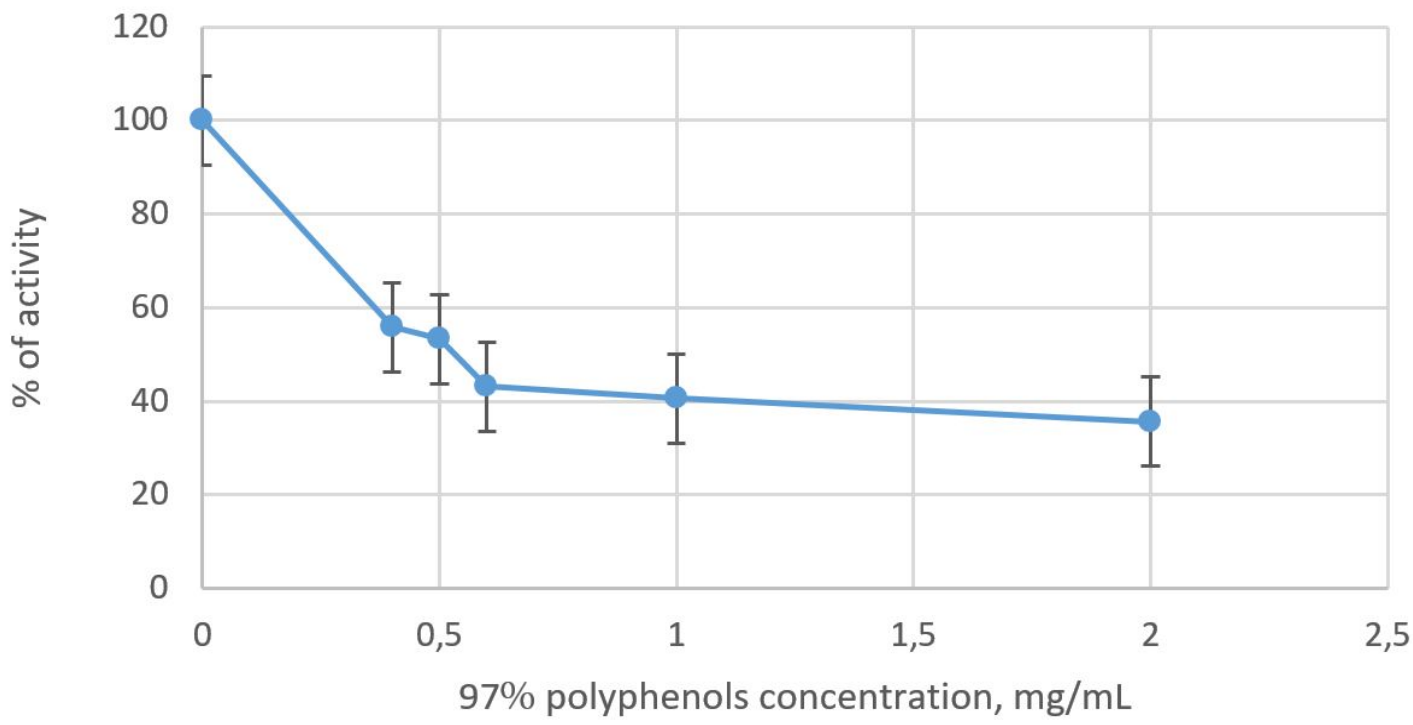

Figure 2. Inhibition of the lipase activity by different concentrations of $97 \%$ green tea polyphenol compounds.

\section{Conclusions}

Green tea, citrus peels and red wine lees were found to be the richest and commercially reasonable sources of polyphenols. Based on this finding, novel food composites were produced from green tea extract, red wine lees and lemon peels. The plant materials used were by products of the tea, wine and citrus industries and were therefore relatively cheap, as well as commercially available in Georgia. The composites obtained were rich in polyphenols, pectin, amino acids and other bioactive compounds and showed high antioxidant, antilipase and good or moderate antimicrobial activities against some microorganisms. They may be recommended as novel sources of nutraceuticals for the food and pharmaceutical industries. 
Gulua, L. et al.

\section{Acknowledgements}

This research was carried out in the framework of the research project financed by the Shota Rustaveli National Science Foundation (SRNSF), no. 217416.

\section{References}

Aprikian, O., Duclos, V., Guyot, S., Besson, C., Manach, C., Bernalier, A., Morand, C., Remesy, C., \& Demigne, C. (2003). Apple pectin and a polyphenol-rich apple concentrate are more effective together than separately on cecal fermentations and plasma lipids in rats. The Journal of Nutrition, 133(6), 1860-1865.

Assini, J. M., Mulvihill, E. E., \& Huff, M. W. (2013). Citrus flavonoids and lipid metabolism. Current Opinion in Lipidology, 24(1), 34-40. PMid:23254473. http://dx.doi.org/10.1097/MOL.0b013e32835c07fd

Balik, J., Kyseláková, M., Vrchotová, N., Tř́lska, J., Kumśta, M., Veverka, J., HÍc, P., Totušek, J., \& Lefnerová, D. (2008). Relations between polyphenols content and antioxidant activity in vine grapes and leaves. Czech Journal of Food Sciences, 26(Special Issue), S25-S32. https://doi.org/10.17221/246/2008-CJFS.

Balouiri, M., Sadiki, M., \& Ibnsouda, S. K. (2016). Methods for in vitro evaluating antimicrobial activity: a review. Journal of Pharmaceutical Analysis, 6(2), 71-79. PMid:29403965. http://dx.doi.org/10.1016/j.jpha.2015.11.005

Belitz, H. D., Grosch, W., \& Schieberle, P. (2009). Food chemistry. Heidelberg: Springer.

Benzie, I. F. F., \& Strain, J. J. (1996). The ferric reducing ability of plasma (FRAP) as a measure of antioxidant power: the FRAP assay. Analytical Biochemistry, 239(1), 70-76. PMid:8660627. http://dx.doi.org/10.1006/abio.1996.0292

Birari, R. B., \& Bhutani, K. K. (2007). Pancreatic lipase inhibitors from natural sources: unexplored potential. Drug Discovery Today, 12(19-20), 879-889.

Blumenkrantz, N., \& Asboe-Hansen, G. (1973). New method for quantitative determination of uronic acids. Analytical Biochemistry, 54(2), 484-489. PMid:4269305. http://dx.doi.org/10.1016/0003-2697(73)90377-1

Bond, T. J., Lewis, J. R., Davis, A., \& Davis, A. P. (2003). Analysis and purification of catechins and their transformation products. In C. Santos-Bulga \& G. Williamson (Eds.), Methods in polyphenols analysis (pp. 229-259. London: The Royal Society of Chemistry.

Chanet, A., Milenkovic, D., Manach, C., Mazur, A., \& Morand, C. (2012). Citrus flavanones: what is their role in cardiovascular protection? Journal of Agricultural and Food Chemistry, 60(36), 8809-8822. PMid:22574825. http://dx.doi.org/10.1021/jf300669s

Cook, N. C., \& Saman, S. (1996). Flavonoids-chemistry, metabolism, cardioprotective effects, and dietary sources. The Journal of Nutritional Biochemistry, 7(2), 66-76. http://dx.doi.org/10.1016/0955-2863(95)00168-9

Coppo, E., \& Marchese, A. (2014). Antibacterial activity of polyphenols. Current Pharmaceutical Biotechnology, 15(4), 380-390. PMid:25312620. http://dx.doi.org/10.2174/138920101504140825121142

Corina, C. P., Nicorescu, P. V., \& Stefan, G. (2017). Comprehensive reviews. Food Science and Food Safety, 17(5), $1243-1268$. Cowan, M. M. (1999). Plant products as antimicrobial agents. Clinical Microbiology Reviews, 12(4), 564-582. PMid:10515903. http://dx.doi.org/10.1128/CMR.12.4.564

Feng, R., Ni, H. M., Wang, S. Y., Tourkova, I. L., Shurin, M. R., Harada, H., \& Yin, X. M. (2007). Cyanidin-3-rutinoside, a natural polyphenol antioxidant, selectively kills leukemic cells by induction of oxidative stress. The Journal of Biological Chemistry, 282(18), 13468-13476. PMid:17360708. http://dx.doi.org/10.1074/jbc.M610616200

Friedman, M. (2004). Applications of the ninhydrin reaction for analysis of amino acids, peptides, and proteins to agricultural and biomedical sciences. Journal of Agricultural and Food Chemistry, 52(3), 385-406. PMid:14759124. http://dx.doi.org/10.1021/jf030490p

Gilles, M. A., Frank, N. E. G., Tatsadjieu, L., Nicolas, N. Y., \& Mbofung, C. M. F. (2015). Assessment of in vitro inhibitory effect of khaya tea infusion on porcine pancreatic lipase activity. International Journal of Biological Sciences, 6(6), 1-9.

Gondoin, A., Grussu, D., Stewart, D., \& McDougall, G. J. (2010). White and green tea polyphenols inhibit pancreatic lipase in vitro. Food Research International, 43(5), 1537-1544.

Hakim, I. A., \& Harris, R. B. (2001). Joint effects of citrus peel use and black tea intake on the risk of squamous cell carcinoma of the skin. BMC Dermatoljgy, 1(3), 3.

Halliwell, B. (1994). Free radicals, antioxidant and human disease: curiosity, cause or consequence? Lancet, 344(8924), 721 724. PMid:7915779. http://dx.doi.org/10.1016/S0140-6736(94)92211-X

Kader, A. A., \& Barret, D. M. (2005). Classification, composition of fruits, and post harvest maintenance of quality. In D. Barret, L. Somogyie \& H. Ramaswamy (Eds.), Processing fruits (pp. 5-21). Boca Raton: CRC Press.

Kang, J. G., \& Park, C. Y. (2012). Anti-obesity drugs: a review about their effects and safety. Diabetes \& Metabolism Journal, $36(1), 13-25$.

Landeka, I., Jurčević, Dora, M., Guberović, I., Petras, M., Rimac, S., Brnčić, \& Đikić, D. (2017). Polyphenols from Wine Lees as a Novel Functional Bioactive Compound in the Protection Against Oxidative Stress and Hyperlipidaemia. Food Technology and Biotechnology, 55(1), 109-116. 
Chemical constituents, antioxidant, antimicrobial and anti-lipase activities of composites derived from green tea, lemon peels and red wine lees

Gulua, L. et al.

Lunagariya, N. A., Patel, N. K., Jagtap, S. C., \& Bhutani, K. K. (2014). Inhibitors of pancreatic lipase: state of the art and clinical perspectives. EXCLI Journal Experimental and Clinical Sciences, 13, 897-921. PMid:26417311.

Pandey, K. B., \& Rizvi, S. I. (2009). Plant polyphenols as dietary antioxidants in human health and disease. Oxidative Medicine and Cellular Longevity, 2(5), 270-278. PMid:20716914. http://dx.doi.org/10.4161/oxim.2.5.9498

Papuc, C., Goran, G. V., Predescu, C. N., Nicorescu, V., \& Stefan, G. (2017). Plant polyphenols as antioxidant and antibacterial agents for shelf-life extension of meat and meat products: classification, structures, sources, and action mechanisms. Comprehensive Reviews in Food Science and Food Safety, 16(6), 1243-1268.

Rasouli, H., Farzaei, M. H., \& Khodarahmi, R. (2017). Polyphenols and their benefits: A review. International Journal of Food Properties, 20(2), 1700-1741.

Stoytcheva, M., Montero, G., Zlatev, R., Leon, J. A., \& Gochev, V. (2012). Analytical methods for lipases activity determination: a review. Current Analytical Chemistry, 8(3), 400-407. http://dx.doi.org/10.2174/157341112801264879

Tejero-Sariñena, S., Barlow, J., Costabile, A., Gibson, G. R., \& Rowland, I. (2012). In vitro evaluation of the antimicrobial activity of a range of probiotics against pathogens: evidence for the effects of organic acids. Anaerobe, 18(5), 530-538.

Tewari, S., Gupta, V., \& Bhattacharya, S. (2000). Comparative study of antioxidant potential of tea with and without additives. Indian Journal of Physiology and Pharmacology, 44(2), 215-219. PMid:10846639.

Turmanidze, T., Zhgenti, M., Gurielidze, M., \& Gulua, L. (2016). Chemical constituents, antioxidant and antimicrobial activities of novel food additives derived from plant material. International Journal of Management and Applied Science, 2(5), 123-125.

Funding: Shota Rustaveli National Science Foundation (SRNSF),

no. 217416. 